\section{Integrated Assessment of Hydro-Climatology Variability in Kamo River Basin: Confronting Climate and Extremes}

\section{Maochuan $\mathrm{Hu}^{\mathrm{a}^{*}}$, Kaoru Takara ${ }^{\mathrm{a}}$, Weili Duan $^{b}$, Bin $_{\mathrm{He}^{b}}{ }^{\mathrm{b}}$ and Pingping Luo}

${ }^{a}$ Kyoto University, Disaster Prevention Research Institute (DPRI), Kyoto University, Uji, Kyoto 611-oo11, Japan

${ }^{b}$ Nanjing Institute of Geography and Limnology, East Beijing Road 73, Nanjing 210o86, China

${ }^{c}$ Institute for the Advanced Study of Sustainability, United Nations University, Jingumae 5-53-70, Tokyo 150-8925, Japan

Received: April 15, 2015 / Accepted: May 28, 2015

\section{Abstract}

One of the most urgent global issues of our time is how to build a sustainable society to cope with climatic changes and associated water-related hazards. Understanding how changes in precipitation, temperature and evapotranspiration impact runoff yield, and the resulting discharge, is significant for the sustainable management of water resources. The Hydrological Predictions for the Environment (HYPE) model and statistical methods were employed to evaluate the effects of climate and extremes on water resources in Kamo River Basin (KRB). Climate change has been taking place in recent decades in $\mathrm{KRB}$, as reflected by a decrease in annual and seasonal precipitation amounts, while an increase in the annual and seasonal mean temperatures has also been observed. In addition, extreme short-term precipitation became less frequent and smaller, as indicated by the lowering of extreme indices from 1951 to 2010. The HYPE-simulated hydrological variables presented large variations, possibly due to the influence of climate change. Annual and seasonal surface runoff and stream-flow have shown a decreasing tendency. There was a decrease of more than $60 \mathrm{~mm}$ in the mean annual and flood seasonal (March to October) surface runoff in the period 1981-2010, in comparison to the period 1951-1980. The variations in hydrological extreme indices indicate that extreme shortterm flood became less frequent and smaller from 1951 to 2010. In addition, precipitation had more influence on

Corresponding Author Tel.: +81-774314129; Fax.: +81-774314130; E-mail: hu-maochuan@163.com evapotranspiration than temperature at annual and flood seasonal timescales. The annual and flood seasonal evapotranspiration had the same declining trends as precipitation. The findings of hydro-climatic characteristics in KRB indicate that the main problem for water sustainable management in the area relates to how to mitigate the increasing probability of drought.

Keywords: Climate change; Extreme indices; Hydrology; HYPE; Statistic.

Abbreviations:
\begin{tabular}{|lll|}
\hline KRB & $:$ & Kamo River Basin \\
HYPE & $:$ & Hydrological Predictions for the Environment \\
NSE & $:$ & Nash-Sutcliff Efficiency \\
\hline
\end{tabular}

\section{Introduction}

Ongoing climate change processes have been significantly affecting water resources distribution and the intensities and frequencies of hydro-meteorological extreme events [1, 2]. It is very likely that there have been statistical significant increases in the number of heavy precipitation events over most of the mid-latitude land masses and wet tropical regions, as mentioned in the Fifth Assessment Report of the Intergovernmental Panel on Climate Change (5AR IPCC). Extreme climate events and their changes are highly related to human society, as emphasized in the Special Report on Extreme Events of IPCC. Understanding how changes in precipitation, temperature and evapotranspiration impact runoff yield, and the resulting discharge, is a significant problem for the sustainable water management $[3,4]$.

To date, a number of studies have been conducted to ascertain evidence and the impacts of climate change on hydro-climatology in the world [5-8]. Decreasing rainfall and rising temperature in south-western Australia have resulted in surface water being less used on a proportional basis compared with groundwater, and this substitution of sources is likely to increase in future [9]. Öztürk et al. (2013) [10] reported that the water budget was most sensitive to variations in precipitation and conversion between forest and agricultural lands in the Bartin spring watershed, Turkey. Mann and Gleick (2015) [11] analyzed California drought in the early 21st century and reported that it is likely that the droughts California will experience in the future will become more severe due to climate change. A decrease in wet and warm seasonal stream-flow (and annual stream-flow) due to climate change over the past decades was found in the upper Yellow River Basin, China by Cuo et al. (2013) [5]. However, most studies have so far focused on long-term average hydrological changes in terms of annual, seasonal or monthly characteristics. Assessments of water resources changes from the perspective of extremes are not 
Detection and Indices (ETCCDI) developed 27 core indices to describe and estimate climate extremes [17]. The ETCCDI climate change indices have been widely used for assessing extreme changes due to their robustness and fairly straightforward calculation and interpretation [17-19].

There is abundant evidence of the impact of climate change on hydro-meteorology in Japan [20]. Water-related disasters are likely to occur more frequently because of abnormal changes of temperature and precipitation [21-23]. However, hydrological responses to climate change are different from place to place. It is necessary to conduct a study of hydrological variation under climate change on regions where few studies have been previously carried out, in order to provide information that can guide the sustainable water management practices. Kamo River, which flows through Kyoto city, eventually empties into Katsura River, supporting about 1.5 million residents. The Kamo River Basin (KRB), considered the historical political, socioeconomic and cultural center of Japan, is an important tourist attraction and many landscape cultural activities in the area rely on its water resources. Also, the basin is vulnerable to floods and suffered several disastrous flooding events in history. In addition, Kamo River is an important habitat of freshwater fish, which are sensitive to changes in water level [24]. Furthermore, the Kamo River bank is a popular place for sightseeing. There are open pathways along the river during the dry season. The variations of water resources in Kamo River associated with climate change are likely to have great impact on the river ecosystem and tourist economy. The effects of climate change on stream-flow variations in KRB were analyzed by using a hydrological model by Hu et al. [25]. However, this research only discussed annual and seasonal variations and neglected the changes in hydrological variables related to climate extremes.

Therefore, this study, using the work of $\mathrm{Hu}$ et al. [25] as its starting point, aims to identify climate extremes changes by the use of "extreme indices" and quantify water resources variations related to climate change, especially extremes changes in hydrology. The ultimate goal is to provide information for water resource managers that can help to understand hydrology variations and plan decisions associated with water related environmental change.

\section{Study Area}

The KRB, located around the area of Kyoto city in the western part of Japan, is a sub-basin of the Yodo River Basin (Fig. 1). It has a total area of about $210 \mathrm{~km}^{2}$, with mountain terrain comprising about $70 \%$ of the surface. The average annual precipitation (1951-2010) was about $1580 \mathrm{~mm}$ and the mean daily air temperature was around $15 \cdot 6^{\circ} \mathrm{C}$.

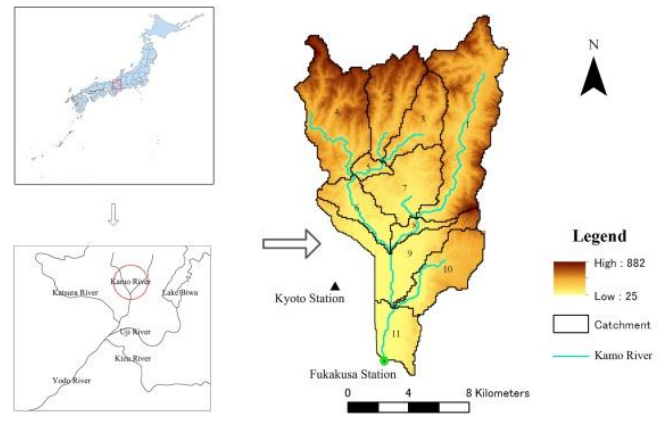

Figure 1 The location and DEM of Kamo River Basin
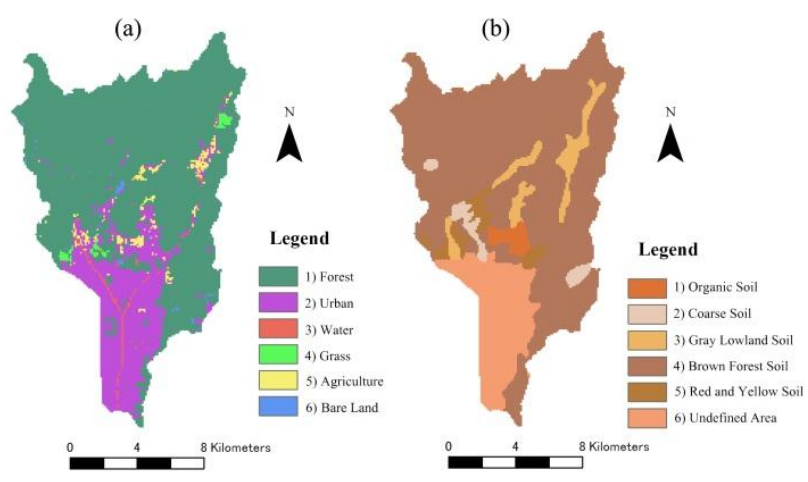

Figure 2 (a) Land use map of KRB (b) Soil type map of KRB

\section{Data and Method}

\subsection{The Hydrological Predictions for the Environment (HYPE) model}

The Hydrological Predictions for the Environment model $[26,27]$ was applied to investigate the effects of climate change on the hydrology of KRB. HYPE is a semidistributed, dynamical hydrological model forced with time series of precipitation and air temperature, typically on a daily time step. It can simulate water flows in the landscape at the catchment scale. A pre-study has confirmed that HYPE can adequately simulate KRB [25]. In addition, a number of studies also reported a good performance of HYPE on simulating stream-flows in a range of climate conditions and resolutions [26-30].

In a HYPE model set-up the basin is divided into subbasins, which are further divided into fractions based on, for example, land use and soil type. These are called hydrological response units (HRUs). HYPE calculations are based on the water balance in the soil profile and the following functions are simulated (note that the list is not exhaustive): precipitation and snow pack, soil moisture and evapotranspiration, surface and soil runoff. The detailed 
calculation method of each model component can be found in literature [26].

Calibration of HYPE is automatically carried out based on a Monte Carlo simulation method, which is a module of the model. To assess the performance of the model calibration, the Nash-Sutcliff efficiency (NSE) and correlation coefficient (CC) between observations and simulations are calculated. NSE measures the efficiency of a model by relating the errors to the variance in the observations [27]. Larger NSE values indicate better model performance and a perfect fit corresponds to NSE $=1$.

$$
N S E=1-\frac{\sum_{i=1}^{n}(O-S)^{2}}{\sum_{i=1}^{n}(O-\bar{O})^{2}}
$$

Where $\mathrm{O}$ and $\mathrm{S}$ are the observed and simulated data, respectively, and $\mathrm{n}$ is the total number of data records [27].

\subsection{Dataset}

The dataset contains daily precipitation and temperature from 1951 to 2010 at Kyoto station obtained from the Japan Meteorological Agency. No missing and unrealistic records were found in the climatic data. The 5om DEM of KRB, land use map of 2006, and soil type stemmed from the Nation and Regional Planning Bureau of the Japan Ministry of Land, Infrastructure, Transport and Tourism (MLIT). The land use map is presented in Fig. 2(a), which shows that KRB is occupied mostly by forest $(74.25 \%)$, urban $(21.26 \%)$, water $(1.06 \%)$, grass $(0.74 \%)$, agriculture $(2.26 \%)$, and bare lands (0.43\%). Fig. 2(b) shows the soil map and its percentage distribution: 1) Organic Soil $(1.7 \%), 2)$ Coarse Soil $(2.4 \%), 3)$ Gray Lowland Soil $(5.4 \%), 4)$ Brown Forest Soil $(72.1 \%)$, 5) Red and Yellow Soil (3.2\%), and 6) Ungauged Area (15.2\%).

In order to drive the HYPE simulations, the DEM, land use and soil type data were processed in a Geographic Information System (GIS). First, according to the 5om DEM the basin was divided into 11 sub-basins (Fig. 1) by means of a hydrological analysis. Then, the land use and soil maps were combined to create hydrological response units.

Daily stream-flow data at Fukakusa station $\left(34^{\circ} 57^{\prime} 58^{\prime \prime} \mathrm{N}\right.$, $\left.135^{\circ} 45^{\prime} 33^{\prime \prime} \mathrm{E}\right)$ was obtained from MLIT. However, the data was less than 10 years long and there was a discontinuity in it (1991-1995 and 2002-2005). In addition, there were 50 days missing in 2002. The observed stream-flow data were used to calibrate and validate HYPE.

\subsection{Analysis of hydro- climatology changes}

In a previous study by $\mathrm{Hu}$ et al. [25] the variables of annual and seasonal precipitation and temperature were used to evaluate climate change. However, the variables employed in the study by Hu et al. [25] cannot demonstrate changes in climate extremes. Thus, in the present study five indices
(Table 1) were selected to estimate extremes, recommended by the study of Duan [31] and the ETCCDI [17]. Moreover, indices of stream-flow corresponding to extremes were also developed.

Trend analysis was carried out using the Mann Kendall Test (MKT) for monotonic trends to determine whether statistical trends exist in the measures of extremes in the time series. MKT is a non-parametric hypothesis test for statistical procedures [32]. The null hypothesis is that the data used for test is independent and randomly ordered. If the statistics results provided by MKT have a value of less than o this implies a decreasing trend, and if more than o an increasing trend.

Table 1 Definitions of hydro-climatology indices used in this study

\begin{tabular}{|c|c|c|c|c|}
\hline & ID & $\begin{array}{c}\text { Indicator } \\
\text { name }\end{array}$ & Definitions & Units \\
\hline \multirow{4}{*}{$\begin{array}{l}\text { Indices of } \\
\text { climate } \\
\text { extremes }\end{array}$} & RXiday & $\begin{array}{l}\text { Max 1-day } \\
\text { precipitation } \\
\text { amount }\end{array}$ & $\begin{array}{l}\text { Annual } \\
\text { maximum 1- } \\
\text { day } \\
\text { precipitation }\end{array}$ & $\mathrm{mm}$ \\
\hline & CDD & $\begin{array}{c}\text { Consecutive } \\
\text { dry days }\end{array}$ & $\begin{array}{l}\text { Maximum } \\
\text { consecutive } \\
\text { days with DR } \\
<\text { 1mm }\end{array}$ & $\mathrm{d}$ \\
\hline & Rzomm & $\begin{array}{l}\text { Heavy } \\
\text { rainfall days }\end{array}$ & $\begin{array}{l}\text { Annual count } \\
\text { of days when } \\
\text { DR>=20mm }\end{array}$ & $\mathrm{d}$ \\
\hline & TXıday & $\begin{array}{c}\text { Max 1-day } \\
\text { mean } \\
\text { temperature }\end{array}$ & $\begin{array}{l}\text { Annual } \\
\text { maximum 1- } \\
\text { day mean } \\
\text { temperature }\end{array}$ & ${ }^{\circ} \mathrm{C}$ \\
\hline \multirow{2}{*}{$\begin{array}{l}\text { Indices of } \\
\text { hydrological } \\
\text { extremes }\end{array}$} & SRXıday & $\begin{array}{l}\text { Max 1-day } \\
\text { surface } \\
\text { runoff } \\
\text { amount }\end{array}$ & $\begin{array}{l}\text { Annual } \\
\text { maximum 1- } \\
\text { day surface } \\
\text { runoff }\end{array}$ & $\mathrm{mm}$ \\
\hline & SXıday & $\begin{array}{l}\text { Max 1-day } \\
\text { mean } \\
\text { stream-flow }\end{array}$ & $\begin{array}{c}\text { Annual } \\
\text { maximum 1- } \\
\text { day mean } \\
\text { stream-flow }\end{array}$ & $\mathrm{m}^{3} / \mathrm{s}$ \\
\hline
\end{tabular}

DR is daily rainfall.

In addition, the time series from 1951 to 2010 was equally divided into two periods, 1951-1980 ( $\left.\mathrm{P}_{1}\right)$ and 1981-2010 ( $\left.\mathrm{P}_{2}\right)$. The differences of climatic and hydrological variables between the two periods were calculated to evaluate climate and hydrological changes.

\section{Result}

\subsection{Model calibration and validation}

The HYPE model was calibrated and validated in the study by $\mathrm{Hu}$ et al. [25], which showed that the methodology employed by those authors could accurately simulate the KRB (Table 2). Thus, the values of the parameters used in the present study were the same as those calibrated by $\mathrm{Hu}$ et al. [25]. There were over 15 parameters calibrated in the 
study by $\mathrm{Hu}$ et al. [25] and the 6 parameters that had highest sensitivity to model outcomes are shown in Table 3 .

Table 2 Statistics in the calibration and validation

\begin{tabular}{lccc}
\hline & Periods & NSE & Correlation Coefficient \\
\hline Calibration & $2003^{-2005}$ & 0.72 & 0.87 \\
Validation & $1993^{-1995}$ & 0.69 & 0.83 \\
\hline
\end{tabular}

Table 3 Some of calibrated parameters and their values in the hydrological simulation

\begin{tabular}{|c|c|c|}
\hline Parameter & Description & Optimal Value \\
\hline CEVP & Evapotranspiration factor & $\begin{array}{l}\text { Land-use dependent } \\
\text { (o.1-0.21) }\end{array}$ \\
\hline WCWP & Wilting point as a fraction & $\begin{array}{l}\text { Soil-type dependent } \\
\text { (0.08-0.1) }\end{array}$ \\
\hline WCFC & Field capacity (mm/depth) & $\begin{array}{l}\text { Soil-type dependent } \\
\text { (0.07-0.33) }\end{array}$ \\
\hline WCEP & $\begin{array}{l}\text { Effective porosity } \\
\text { (mm/depth) }\end{array}$ & $\begin{array}{c}\text { Soil-type dependent } \\
\text { (0.06-0.24) }\end{array}$ \\
\hline $\mathrm{RRCS}_{1}$ & $\begin{array}{c}\text { Recession coefficient for top } \\
\text { soil layer }\end{array}$ & $\begin{array}{l}\text { Soil-type dependent } \\
\text { (0.14-0.5) }\end{array}$ \\
\hline RIVVEL & Peak velocity of stream (m/s) & General (1.68) \\
\hline
\end{tabular}

\subsection{Climatic changes}

Trend analysis was conducted for annual, flood (from March to October) and dry (from November to next February) seasonal rainfall and mean temperature, and all indices of extremes. The results are shown in Fig. 3 and Table 4. All temperature indices had significant increasing trends with time. Annual and flood seasonal precipitation amounts tended to rise, while a non-statistic decreasing trend also appeared for dry seasonal precipitation. Variations in the extreme indices of maximum daily precipitation (RXıday) and heavy precipitation days (R2omm) showed a decreasing trend. As a consequence of this the index of consecutive dry days (CDD) increased.

Table 4 Trend analysis for changes in climate

\begin{tabular}{|c|c|c|c|c|c|}
\hline Item & $\mathrm{Z}$ & $\mathbf{P}$ & Item & $\mathrm{Z}$ & $\mathbf{P}$ \\
\hline $\begin{array}{c}\text { Annual } \\
\text { Precipitation }\end{array}$ & -2.66 & $\mathrm{Y}$ & $\begin{array}{c}\text { Annual Mean } \\
\text { Temperature }\end{array}$ & $5 \cdot 73$ & $\mathrm{Y}$ \\
\hline $\begin{array}{l}\text { Flood seasonal } \\
\text { Precipitation }\end{array}$ & -3.01 & $\mathrm{Y}$ & $\begin{array}{l}\text { Flood seasonal } \\
\text { mean Temperature }\end{array}$ & $5 \cdot 38$ & $\mathrm{Y}$ \\
\hline $\begin{array}{l}\text { Dry seasonal } \\
\text { Precipitation }\end{array}$ & 0.1 & $\mathrm{~N}$ & $\begin{array}{l}\text { Dry seasonal mean } \\
\text { Temperature }\end{array}$ & 3.9 & $\mathrm{Y}$ \\
\hline RX1day & -1.18 & $\mathrm{~N}$ & TXıday & 4.9 & $\mathrm{Y}$ \\
\hline CDD & 1.7 & $\mathrm{Y}$ & R2omm & -2.09 & $\mathrm{Y}$ \\
\hline
\end{tabular}

$\mathrm{Z}$ are statistics from MKT; $\mathrm{Y}$ means significant at the level of $\mathrm{P}=\mathrm{0.05}$

Table 5 Differences in climatic indices between $\mathrm{P}_{1}$ (1951-1980) and P2 (1981-2010)

\begin{tabular}{llllll}
\hline Item & & $\begin{array}{l}1951^{-} \\
1980\end{array}$ & $\begin{array}{l}1981- \\
\mathbf{2 0 1 0}\end{array}$ & $\begin{array}{l}\text { Changes } \\
\text { Value }\end{array}$ & $\begin{array}{l}\text { Percentage } \\
(\%)\end{array}$ \\
\hline $\begin{array}{l}\text { Mean } \\
\text { precipitation } \\
(\mathrm{mm})\end{array}$ & $\begin{array}{l}\text { Annual } \\
\text { Flood }\end{array}$ & 1668.9 & 1491.3 & -177.6 & -10.6 \\
& $\begin{array}{l}\text { season } \\
\text { Dry }\end{array}$ & 244.3 & $\mathbf{2 3 7 . 9}$ & -6.4 & -2.6 \\
\hline
\end{tabular}

\begin{tabular}{|c|c|c|c|c|c|}
\hline \multirow{4}{*}{$\begin{array}{l}\text { Mean } \\
\text { Temperature } \\
\left({ }^{\circ} \mathrm{C}\right)\end{array}$} & \multicolumn{5}{|l|}{ season } \\
\hline & Annual & 15.2 & $15 \cdot 9$ & 0.7 & 4.6 \\
\hline & $\begin{array}{l}\text { Flood } \\
\text { season }\end{array}$ & 19.5 & 20.2 & 0.7 & 3.6 \\
\hline & $\begin{array}{l}\text { Dry } \\
\text { season }\end{array}$ & 6.6 & 7.2 & 0.6 & 9.1 \\
\hline Average RXıda & $(\mathrm{mm})$ & 118.2 & 108.7 & -9.5 & -8 \\
\hline
\end{tabular}

Table 5 illustrates the relative changes of precipitation and temperature between the periods of $1951-1980(\mathrm{P} 1)$ and 1980-2010 $\left(\mathrm{P}_{2}\right)$. It is clear that the variances correspond to the results of the trend analysis except average dry seasonal rainfall, which decreased $2.6 \mathrm{~mm}$ from $\mathrm{P}_{1}$ to $\mathrm{P}_{2}$. Average annual and flood seasonal rainfall reduced more than $10 \%$. A warming trend was obvious during the dry season, increasing by about $9 \%$. The average extreme annual maximum 1-day precipitation decreased $9.5 \mathrm{~mm}$.

\subsection{Impacts of climatic change}

In order to illustrate how water resources respond to climate change, the variables of stream-flow, surface runoff and evapotranspiration and the hydrological extreme indices (listed in Table 1) were analyzed. The results of the trend analysis were presented in Table 6 and Fig. 4. Annual and flood seasonal surface runoff tended to rise, while there was a non-statistic significant decreasing trend for dry seasonal runoff. All variables of stream-flow had decreasing trends. Dry seasonal evapotranspiration seemed to increase, whereas there was a non-statistical significant decreasing trend for annual and flood seasonal evapotranspiration. Variations in the extreme indices of SRXıday and SXıday indicated a decreasing trend. 

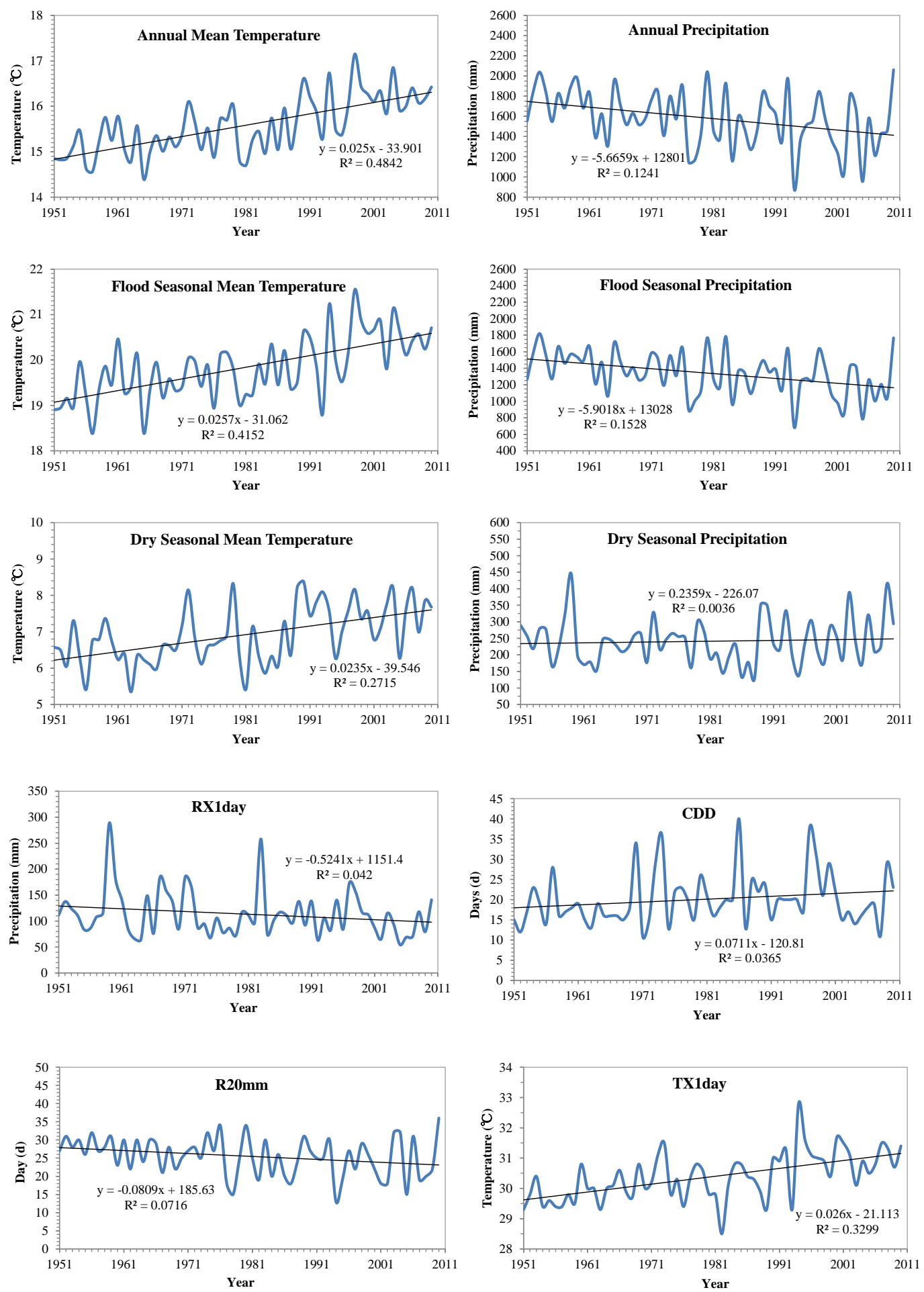

Figure 3 Linear trends in climatic change in the period 1951-2010 

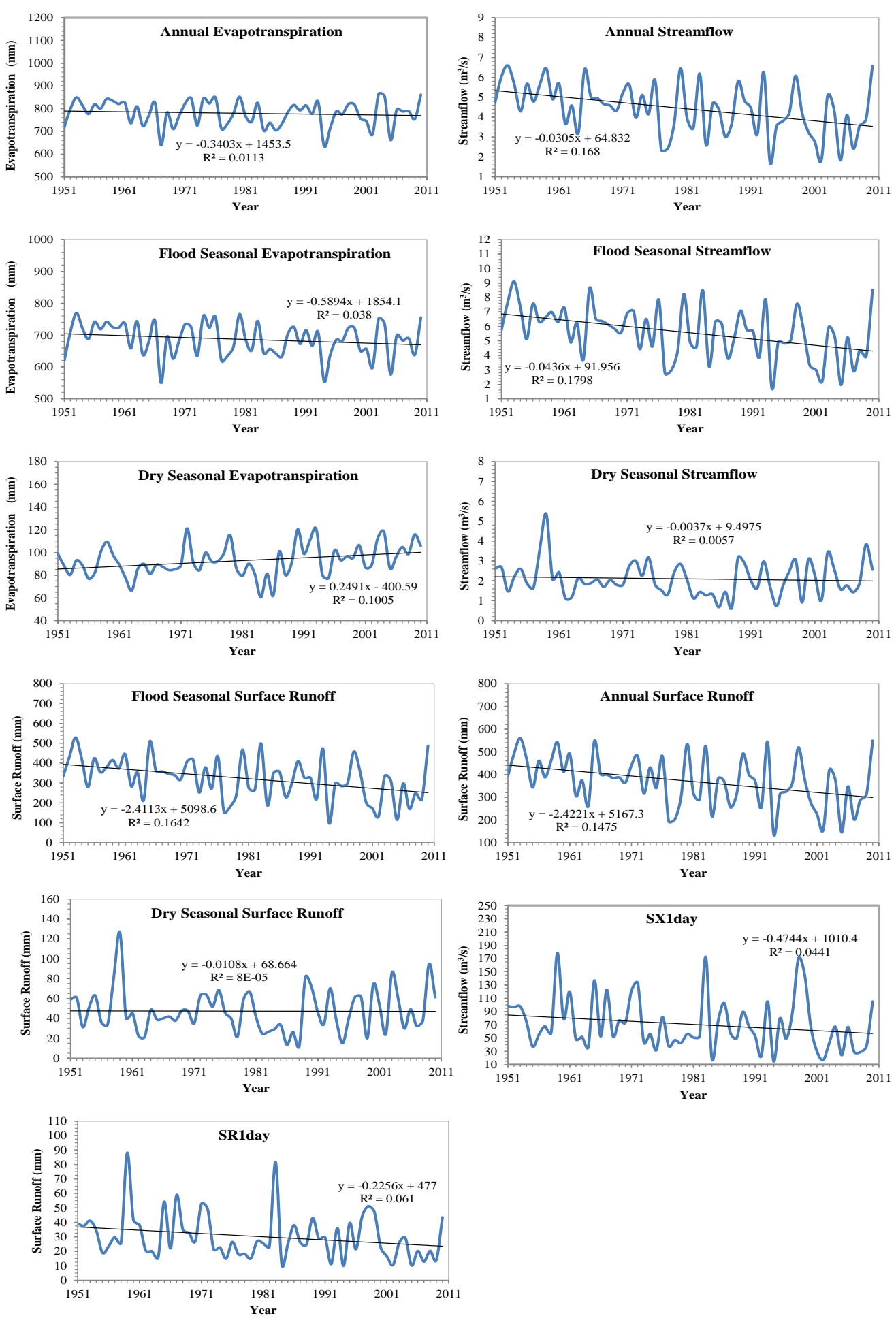

Fig. 4 Linear trends in hydrological change in the period 1951-2010 
Table 6 Trend analysis for hydrological variables and extremes

\begin{tabular}{|c|c|c|c|c|c|}
\hline Item & $\mathbf{Z}$ & $\mathbf{P}$ & Item & $\mathbf{Z}$ & $\mathbf{P}$ \\
\hline $\begin{array}{l}\text { Annual surface } \\
\text { runoff }\end{array}$ & -3.16 & $\mathrm{Y}$ & $\begin{array}{l}\text { Annual seasonal } \\
\text { stream-flow }\end{array}$ & -3.26 & $\mathrm{Y}$ \\
\hline $\begin{array}{l}\text { Flood seasonal } \\
\text { surface runoff }\end{array}$ & $-3 \cdot 3$ & $\mathrm{Y}$ & $\begin{array}{l}\text { Flood seasonal } \\
\text { stream-flow }\end{array}$ & $-3 \cdot 37$ & $\mathrm{Y}$ \\
\hline $\begin{array}{l}\text { Dry seasonal } \\
\text { surface runoff }\end{array}$ & 0.02 & $\mathrm{~N}$ & $\begin{array}{l}\text { Dry seasonal } \\
\text { stream-flow }\end{array}$ & -0.53 & $\mathrm{~N}$ \\
\hline SRXıday & -2 & $\mathrm{Y}$ & $\begin{array}{c}\text { Annual } \\
\text { evapotranspiration }\end{array}$ & -0.66 & $\mathrm{~N}$ \\
\hline SXıday & -2.03 & $\mathrm{Y}$ & $\begin{array}{l}\text { Dry seasonal } \\
\text { evapotranspiration }\end{array}$ & 2.48 & $\mathrm{Y}$ \\
\hline $\begin{array}{c}\text { Flood seasonal } \\
\text { evapotranspiration }\end{array}$ & -1.36 & $\mathrm{~N}$ & & & \\
\hline
\end{tabular}

$\mathrm{Z}$ are statistics from MKT; $\mathrm{Y}$ means significant at the level of $\mathrm{P}=\mathrm{O} . \mathrm{O} 5$

Table 7 Differences in hydrological indices between $P_{1}$ (1951-1980) and $\mathrm{P}_{2}$ (1981-2010)

\begin{tabular}{|c|c|c|c|c|c|}
\hline \multicolumn{2}{|l|}{ Item } & $\begin{array}{l}1951^{-} \\
1980 \\
\end{array}$ & $\begin{array}{l}1981- \\
2010 \\
\end{array}$ & $\begin{array}{l}\text { Changes } \\
\text { Value }\end{array}$ & Rate (\%) \\
\hline \multirow{3}{*}{$\begin{array}{l}\text { Surface } \\
\text { runoff }(\mathrm{mm})\end{array}$} & Annual & 405.4 & $335 \cdot 3$ & -70.1 & $-17 \cdot 3$ \\
\hline & Flood & 355.8 & 290.3 & -65.5 & -18.4 \\
\hline & dry & 49.6 & 45 & -4.6 & -9.3 \\
\hline \multirow{3}{*}{$\begin{array}{l}\text { Evapotransp } \\
\text { iration } \\
(\mathrm{mm})\end{array}$} & Annual & 788.4 & 770.9 & $-17 \cdot 5$ & -2.2 \\
\hline & Flood & 697.7 & 676.2 & -21.5 & -3.08 \\
\hline & dry & 90.7 & $94 \cdot 7$ & 4 & $4 \cdot 4$ \\
\hline \multirow{3}{*}{$\begin{array}{l}\text { Stream-flow } \\
\left(\mathrm{m}^{3} / \mathrm{s}\right)\end{array}$} & Annual & 4.9 & 4 & -0.9 & -18.4 \\
\hline & Flood & 6.2 & 5 & -1.2 & $-19 \cdot 4$ \\
\hline & dry & 2.2 & 1.9 & -0.3 & -13.6 \\
\hline \multirow{2}{*}{\multicolumn{2}{|c|}{$\begin{array}{l}\text { Average SXıday (mm) } \\
\text { Average SRXıday (mm) }\end{array}$}} & 75.6 & 66.1 & -9.5 & -12.6 \\
\hline & & 32.3 & 28.1 & -4.2 & -13 \\
\hline
\end{tabular}

Furthermore, the variations from period 1951-1980 ( $\mathrm{P} 1)$ to period 1981-2010 $\left(\mathrm{P}_{2}\right)$ were calculated (Table 7$)$. Average dry seasonal surface runoff in period 1981-2010 decreased 9.3\% in comparison to $1951-1980$, which contradicts with the result of trend analysis listed in Table 6. This phenomenon requires more analysis and future study, which is outside of the scope of this paper. Changes in other variables are in accordance with the results of trend analysis. Annual and seasonal stream-flow was reduced more than $10 \%$, while dry seasonal evapotranspiration increased about $4 \%$. There was a more than $60 \mathrm{~mm}$ decrease in average annual and flood seasonal surface runoff. The average extremes of SRXıday and SXIday decreased more than $10 \%$.

\section{Discussion}

\subsection{Uncertainties analysis}

Although the research of $\mathrm{Hu}$ et al. [25] demonstrated that HYPE can accurately simulate the KRB, uncertainties still exist in the simulated results. First, land use changes were neglected, which can have great influence on the HYPEsimulated results in KRB [25]. In addition, not all the HYPE parameters were calibrated, and some of those that were not can have a big effect on the water balance. Thus, there are biases between modeled results and actual values. These biases, however, should not compromise the analysis since results were based on a trend analysis of simulated results and the comparison of the results in different timescales, and did not directly use the calculated values for water resource management.

\subsection{Implications of recent changes in climate}

It is interesting to note that the result of trend analysis of dry seasonal precipitation contradicts with the result of variation analysis from period 1951-1980 to period 1981-2010. Also, there is a same problem in the analysis results of dry seasonal surface runoff. The probable reason is due to the biases in statistics. As at the $95 \%$ confidence level for dry seasonal precipitation and surface runoff the results are not statistically significant it is clear that the MKT method is not suitable for trend analysis of dry seasonal precipitation and surface runoff. Hence, variations in dry seasonal precipitation and surface runoff require more discussion and research in the future.

Another interesting finding is that both precipitation amounts and precipitation extreme indices decreased over the last 60 years. The reducing trend in R2omm and rising trend in CDD indicate that the annual precipitation was clearly reduced. Also, the decrease in RXıday indicates that the intensity of extreme short-term precipitation tended to decrease in the period 1951 to 2010. However, in most regions of Japan extreme short-term precipitation is becoming more frequent and much bigger [22, 31]. Changes in extreme short-term precipitation are of high relevance to the changes of temperature and saturation vapor pressure [22].

\subsection{Implications of climate change impacts}

The simulated and statistical results indicate that climate change might become an issue for future water supplies in KRB. The average annual surface runoff in the period 19511980 reduced by about $70 \mathrm{~mm}$ in comparison to $1981-2010$, resulting in a stream-flow decrease of about $20 \%$. The extreme indices of surface runoff (SRXıday) and stream-flow (SXıday) decreased in accordance with the extreme index of precipitation (RXıday), which means that the extreme short-term flood seemed to be smaller. Also, Tachikawa et al. (2011) [13] found by conducting a runoff simulation that there is clear decrease in daily drought discharge (355th daily discharge in a year which have been sorted from greatest to least) in western Japan in the period of 2015-2039 and 2075-2099.

It is found that the variations in annual and flood seasonal evapotranspiration are not in accordance with the variations in temperature. This is because the impacts of decreased precipitation on evapotranspiration are larger than the impacts of increasing temperature. As shown in Table 5, the annual and flood seasonal precipitation 
decreased by more than $10 \%$ (more than $170 \mathrm{~mm}$ ), while the annual and flood seasonal temperatures increase less than $5 \% \quad\left(0.7{ }^{\circ} \mathrm{C}\right)$. Essentially, potential evapotranspiration depends on temperature but evapotranspiration is also limited by the availability of water in the soil.

\subsection{Water resource management}

KRB is vulnerable to floods and suffered several disastrous flooding events during its history. In addition, as an important cultural landscape and freshwater fish habitat, the variations of water resource in Kamo River are of great relevance to tourism and fish survival. Climate change will thus clearly pose a challenge for the sustainable management of the area due to the growing pressure on water resources from climate change, tourism demand and ecosystem services and protection. The results of this research indicate that the main future challenges due to climate change are likely to the decreasing precipitation and river discharge and increasing consecutive dry days. Although domestic water for the Kyoto area does not originate from KRB but from Lake Biwa, it is necessary to maintain water level for tourism and fish survival during dry season. Low impact development approaches (LIDs) may be good policies to aid sustainable water management, including rainwater harvesting, bio-retention, etc. The effectiveness of LIDs to store water and mitigate water security has been proved in literature [33-36].

In addition, according to the present research extreme, short-term flood events became rarer in the last 60 years. It means that the present flood management policies are adequate to ensure human security in terms of flooding in KRB. Also, the variation of extreme flood represents a significant difference to patters across most other regions of Japan [22, 31]. Apparently, hydrological responses to climate change are different from place to place at different scales. Scientific knowledge about the variations of hydrological cycle is thus clearly the first step in sustainable water management [37, 38], and the present study thus makes a significant contribution in this direction.

\section{Conclusion}

Sustainable water management is a concept that emphasizes the need to consider the long-term future as well as the present $[3,39]$. Scientific knowledge about the variations of hydrological cycle can thus be considered the first step in sustainable water management. Climate variations in KRB during the past decades were characterized by evaluating annual and seasonal precipitation, temperatures and extremes indices. All temperature variables increased from 1951 to 2010. Precipitation amounts exhibited a decrease at both annual and flood season scales. Compared with the period of 19511980 , the average annual and flood seasonal precipitation in the period of 1981-2010 were reduced by more than 170mm. The variations in dry seasonal precipitation require more discussion. The precipitation extremes indices of RXıday and R2omm indicated that the intensity of the extreme short-term precipitation became less frequent and smaller from 1951 to 2010.

The HYPE model was applied to calculate the streamflow, surface runoff and evapotranspiration according to meteorological and topography data. Then, the changes in water resources and hydrology extremes related to climate and climate extremes changes were quantified. At the annual scale, the rising temperature and dropping precipitation resulted in declining stream-flow, runoff and evapotranspiration. At the seasonal scale, climate change has caused falling stream-flow and surface runoff, with evapotranspiration decreasing during the flood season and increasing during the dry season. For the extremes analysis, an obvious decline in SXIday and SRXıday was observed.

The authors thus conclude that present flood management policies in KRB are adequate to protect humans, due to a decreasing trend of extreme short-term flood events, removing the need to improve flood management defenses. However, improving the resilience of society to decreased water resources by following low impact development approaches (e.g. rainwater harvesting, bio-retention, etc.) may be necessary in order to ensure the sustainable water management of the basin.

\section{Acknowledgements}

This study is sponsored by the Kyoto University Global COE Program: "Sustainability/Survivability Science for a Resilient Society Adaptable to Extreme Weather Conditions".

\section{References}

[1] Karl, T. R., Meehl, G. A., Miller, C. D., Hassol, S. J., Waple, A. M., \& Murray, W. L. (2008). Weather and climate extremes in a changing climate. Final Report, Synthesis and Assessment Product, 3 .

[2] Coumou, D., \& Rahmstorf, S. (2012). A decade of weather extremes. Nature Climate Change, 2(7), 491-496.

[3] Loucks, D. P. (200o). Sustainable Water Resources Management. Water International, 25(1), 3-10. doi: 10.1080/02508060008686793

[4] Nakayama, T. (2015). Integrated Assessment System Using Process - Based Eco - Hydrology Model for Adaptation Strategy and Effective Water Resources Management. Remote Sensing of the Terrestrial Water Cycle, 521-535.

[5] Cuo, L., Zhang, Y., Gao, Y., Hao, Z., \& Cairang, L. (2013). The impacts of climate change and land cover/use transition on the hydrology in the upper Yellow River Basin, China. Journal of Hydrology, 502, 37-52.

[6] Arheimer, B., Dahné, J., \& Donnelly, C. (2012). Climate change impact on riverine nutrient load and land-based remedial measures of the Baltic Sea Action Plan. Ambio, 41(6), 6oo-612. 
[7] Cornelissen, T., Diekkrüger, B., \& Giertz, S. (2013). A comparison of hydrological models for assessing the impact of land use and climate change on discharge in a tropical catchment. Journal of Hydrology, 498, 221-236.

[8] Wada, Y., van Beek, L. P., van Kempen, C. M., Reckman, J. W., Vasak, S., \& Bierkens, M. F. (2010). Global depletion of groundwater resources. Geophysical Research Letters, 37(20).

[9] McFarlane, D., Stone, R., Martens, S., Thomas, J., Silberstein, R., Ali, R., \& Hodgson, G. (2012). Climate change impacts on water yields and demands in south-western Australia. Journal of Hydrology, 475, 488-498.

[10] Öztürk, M., Copty, N. K., \& Saysel, A. K. (2013). Modeling the impact of land use change on the hydrology of a rural watershed. Journal of Hydrology, 497, 97-109.

[11] Mann, M. E., \& Gleick, P. H. (2015). Climate change and California drought in the 21st century. Proceedings of the National Academy of Sciences, 112(13), 3858-3859.

[12] Hirabayashi, Y., Mahendran, R., Koirala, S., Konoshima, L., Yamazaki, D., Watanabe, S., Kim, H. \& Kanae, S. (2013). Global flood risk under climate change. Nature Climate Change, 3(9), 816-821. doi: Doi 10.1038/Nclimate1911

[13] Tachikawa, Y., Takino, S., Fujioka, Y., Yorozu, K., Kim, S., and Shiiba, M. (2011). Projection of river discharge of Japanese river basins under a climate change scenario. J. Japan Soc. of Civil Eng. B, 1, 1-15.

[14] Dai, Y., Auchère, F., Vial, J. C., Tang, Y. H., \& Zong, W. G. (2010). Large-scale extreme-ultraviolet disturbances associated with a limb coronal mass ejection. The Astrophysical Journal, $708(2), 913$.

[15] Stocker, T. F., Qin, D., Plattner, G. K., Tignor, M., Allen, S. K., Boschung, J., ... \& Midgley, P. M. (2013). Climate change 2013: The physical science basis. Intergovernmental Panel on Climate Change, Working Group I Contribution to the IPCC Fifth Assessment Report (AR5)(Cambridge Univ Press, New York).

[16] Miyajima, J., \& Fujibe, F. (2011). Climatology of extreme precipitation in Japan for different time scales. $S O L A, 7$, 157-16o.

[17] Sillmann, J., Kharin, V. V., Zhang, X., Zwiers, F. W., \& Bronaugh, D. (2013). Climate extremes indices in the $\mathrm{CMIP}_{5}$ multimodel ensemble: Part 1. Model evaluation in the present climate. Journal of Geophysical Research: Atmospheres, 118(4), 1716-1733.

[18] Alexander, L. V., \& Arblaster, J. M. (2009). Assessing trends in observed and modelled climate extremes over Australia in relation to future projections. International Journal of Climatology, 29(3), 417-435.

[19] Bürger, G., Murdock, T., Werner, A., Sobie, S., \& Cannon, A. (2012). Downscaling extremes-an intercomparison of multiple statistical methods for present climate. Journal of Climate, 25(12), 4366-4388.

[20]Solomon, S. (Ed.). (2007). Climate change 2007-the physical science basis: Working group I contribution to the fourth assessment report of the IPCC (Vol. 4). Cambridge University Press.

[21] Duan, W., He, B., Takara, K., Luo, P., Nover, D., Yamashiki, Y., \& Huang, W. (2014a). Anomalous atmospheric events leading to Kyushu's flash floods, July 11-14, 2012. Natural Hazards, 1-13.

[22] Fujibe, F. (2013). Clausius-Clapeyron-like relationship in multidecadal changes of extreme short-term precipitation and temperature in Japan. Atmospheric Science Letters, 14(3), 127132. doi: $10.1002 / a s l 2.428$
[23] Fujibe, F., Yamazaki, N., Katsuyama, M., \& Kobayashi, K. (2005). The increasing trend of intense precipitation in Japan based on four-hourly data for a hundred years. Sola, 1, 41-44.

[24]Takemon, Y. (1997). Management of biodiversity in aquatic ecosystems: dynamic aspects of habitat complexity in stream ecosystems. In Biodiversity, pp.259-275. Springer New York.

[25] Hu M., Takara K., Luo P., He B. \& Duan W. (2014). Climate Change and Land Use Change Impact Analysis in a Data Sparse Basin Using Hydrological Model. Annual Journal of Hydraulic Engineering (JSCE), Vol.58, 2014.

[26] Lindstrom, G., Pers, C., Rosberg, J., Stromqvist, J., \& Arheimer, B. (2010). Development and testing of the HYPE (Hydrological Predictions for the Environment) water quality model for different spatial scales.

[27] Strömqvist, F., Jönsson, B., \& Strömqvist, B. (2012). Dural lesions in decompression for lumbar spinal stenosis: incidence, risk factors and effect on outcome. European Spine Journal, $21(5), 825-828$.

[28] Jiang, S., Jomaa, S., \& Rode, M. (2013, April). Identification and uncertainty analysis of a hydrological water quality model with varying input data information content. In EGU General Assembly Conference Abstracts (Vol. 15, p. 7094).

[29]Jomaa, S., Jiang, S., \& Rode, M. (2013, April). Effect of increased bioenergy crop production on hydrological response and nutrient emission in central Germany. In EGU General Assembly Conference Abstracts (Vol. 15, p. 13645).

[30]Donnelly, C., Yang, W., \& Dahné, J. (2014). River discharge to the Baltic Sea in a future climate. Climatic Change, 122(1-2), 157170.

[31] Duan, W., Takara, K., He, B., Luo, P., Hu, M., Alias, N., Ishihara, M., \& Yamashiki, Y. (2014b). Changes of precipitation amounts and precipitation extremes in Japan, 1901-2012. Submitted, 2014.

[32] Helsel, D. R., \& Hirsch, R. M. (1992). Statistical methods in water resources (Vol. 49). Elsevier.

[33] HU, M., TAKARA, K., \& ZHANG, X. (2013). Analysis of Optimum Rainwater Tank Size in a Multi-building. Disaster Prevention Research Institute Annuals. B, 56(B), 53-58.

[34] Brontowiyono W., Lupiyanto R., Yuwono E., Sulistiono B., Handayani S., \& Harjito D.A. (2013). Rainwater HarvestingBased Marginal Land Irrigation Technology: A Case Study in Ngawen Sub-district of Gunungkidul Regency, Indonesia. International Journal of Sustainable Future for Human Security Vol, 1, No. 2, 63-67.

[35] Zhang, X., Hu, M., Chen, G., \& Xu, Y. (2012). Urban Rainwater Utilization and its Role in Mitigating Urban Waterlogging Problems-A Case Study in Nanjing, China. Water Resources Management, 26(13), 3757-3766.

[36]Zhang, X. Q., \& Hu, M. C. (2014). Effectiveness of Rainwater Harvesting in Runoff Volume Reduction in a Planned Industrial Park, China. Water Resources Management, 28(3), 671-682. doi: DOI 10.1007/s11269-013-0507-9.

[37] Leelawat, N., Mateo, C. M. R., Gaspay, S. M., Suppasri, A., \& Imamura, F. (2014). Filipinos' Views on the Disaster Information for the 2013 Super Typhoon Haiyan in the Philippines. International Journal of Sustainable Future for Human Security Vol, 2, No. 2, 16-28.

[38] Suryatmojo, H., Fujimoto, M., Yamakawa, Y., Kosugi, K. i., \& Mizuyama, T. (2013). Water balance changes in the tropical rainforest with intensive forest management system. 
International Journal of Sustainable Future for Human Security Vol, 1, No. 2, 56-62

[39] Tuazon, D., Corder G.D., \& McLellan B.C. (2013). Sustainable

Development: A Review of Theoretical Contributions. International Journal of Sustainable Future for Human Security Vol, 1, No. 1, 40-48. 